\title{
Vegetation structure, composition and diversity in relation to the soil characteristics of temperate mixed broad-leaved forest along an altitudinal gradient in Garhwal Himalaya \\ C.M. Sharma*, S.K. Ghildiyal, Sumeet Gairola and Sarvesh Suyal \\ Department of Botany, HNB Garhwal University, Post Box-51, Srinagar Garhwal-246 174, Uttarakhand, India \\ sharmacmin@gmail.com*, skghildiyal@gmail.com, sumeetgairola@gmail.com, sarveshsuyal@gmail.com
}

Abstract: The focus of the study is to characterize the structure, composition and diversity of Banj Oak (Quercus leucotrichophora) forests at different altitudes and slopes in Mandal-Chopta area of Garhwal Himalaya. Competing co-dominant tree layers comprised of Persea duthiei and $D$. himalense at the higher altitude $(2100 \mathrm{~m}$ a.s.I.) and steeper slope $\left(45^{\circ}\right) ; D$. himalense and Betula alnoides at the middle altitude (1700m a.s.l.) and moderate slope $\left(38^{\circ}\right)$; and Lyonia ovalifolia and Myrica esculenta at lower altitude $\left(1550 \mathrm{~m}\right.$ a.s.I.) and gentles slope $\left(30^{\circ}\right)$ were observed in these forests. Community diversity was highest (3.140) at the higher altitude (site-1) whereas the concentration of dominance followed the opposite trend of the diversity. Physico-chemical properties of soils have revealed that availability of higher average total nitrogen and moisture contents might have given birth to higher total basal cover values at middle altitude. The tree density was positively correlated with the tree diversity and tree richness $(P<0.001)$. The vegetational parameters A/F ratio, Shanon-wiener index, Species richness, Margalef index and soil parameters especially $\mathrm{pH}$ and available phosphate ( $\mathrm{kg} / \mathrm{ha}$ ) were significant $(\mathrm{P}<0.05 \%)$ among the forest sites.

Keywords: Banj Oak community, Himalaya, species evenness, vegetation analysis.

Introduction

The Himalayan moist temperate forests are characterized by extensive oak and coniferous forests extending from 1500 to $3000 \mathrm{~m}$ asl. In the Western and Central Himalayas, the three main Oaks provide a simple and convenient basis for subdivision into three altitudinal zones each i.e., Quercus semecarpifolia Sm. (Fagaceae) Kharsu oak in the upper altitudinal zone $(2500 \mathrm{~m}), Q$. floribunda Lindl. ex Royle. (Fagaceae) Moru oak in the

Fig. 1. Climatic data for Mandal-Chopta forest (Source: Forest Dept. of Uttarakhand)

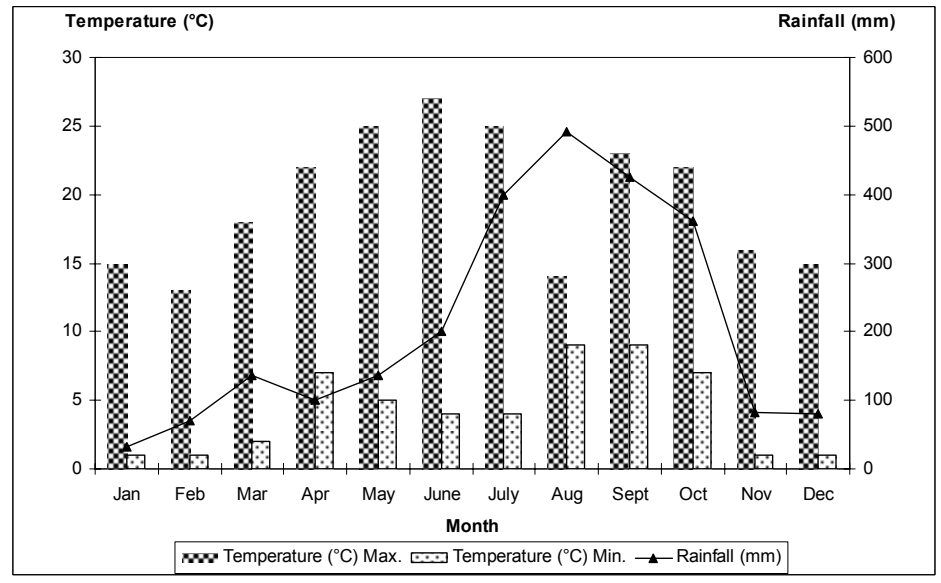

Research article

CIndian Society for Education and Environment (iSee)

"Himalayan flora"

http://www.indjst.org middle zone $(2250 \mathrm{~m})$ and $Q$. leucotirchophora A. Camus. (Fagaceae) Banj oak in the lower altitudinal zone $(2000 \mathrm{~m})$. These oak forests are usually composed of mainly single species depending on the altitude. Puri (1960) and Champion and Seth (1968) considered that these forests represent climatic climax of one or the other species.

Banj oak ( $Q$. leucotroichophora) forests (Forest SubType 12/C1a as per Champion \& Seth, 1968) are evergreen high forests of trees of large girth but medium height, rarely over $25 \mathrm{~m}$ and usually with large branching crowns festooned with mosses, ferns, aroids and other epiphytes. In damp ravines and other favourable sites, there may be an appreciable mixture of deciduous trees contributing to the main canopy. The banj oak forests are exposed to damage or destruction through human agencies, being at a favourable altitude for settlement and cultivation. The species is coppiced regularly near habitations for getting young shoots for quality fodder, which gives a decidedly different appearance from the original undisturbed form. Lopping is extremely prevalent and combined with fuel and a charcoal demand has led to the disappearance of the forests over large areas (Sharma \& Gairola, 2007). These forests are not themselves inflammable, but in many localities suffer a good deal from fires spreading up from the pine zone below.

A plant community is the collection of plant species growing together in a particular location that show a definite association with each other (Muller-Dombois \& Ellengberg, 1974). The most common method of defining this diversity at the ecosystem level is the species. Species diversity is considered as a spatial form of textural diversity and treated both in structure and dynamics of the plant community (Maarel, 1988). However, the concept of diversity is generally concerned with the representation of variability involved in the natural communities. The comparative analysis of species abundance distributions based on species abundance models with associated diversity indices can provide valuable information on the diversity of a community (Magurran, 1988).

Another important biodiversity indicator is the relative (proportional) abundance or degree of dominance of individuals among different species. This is usually referred to as evenness or equitability and measures the extent to which species are equally represented in a community. There exists a strong correlation between structural diversity and species diversity (Sahu et al., 2008). An increase in spatialstructural heterogeneity and habitat complexity is 
equivalent to provision of niches and resources, which usually leads to an enrichment of species (Begon et al. 1990). Conceptual approaches, which distinguish different spatial levels with regard to species diversity and structural diversity have a major disadvantage (Bastian,1990), because they fail to integrate or even mention ecological processes and thereby ignore the functional dimension of biodiversity (Noss, 1990). Although some studies have analyzed the altitudinal and latitudinal forest zones in Himalayas and the surrounding mountains (Tang \& Ohsawa 1997; Wang \& Ohsawa 2006 a, b, c) but there are very few studies available as far as middle temperate zone of Garhwal Himalaya is concerned. According to Franklin (1988) and Noss (1990), three main components of biodiversity can be identified as: (i) composition, (ii) structure, and (iii) function. In the present study therefore, the pattern of community structure, composition and diversity of ecologically distinct Mandal-Chopta forest of Garhwal Himalaya, which receives the full force of monsoon and hitherto form peculiar climate for banj oak growth have been studied along an altitudinal gradient for establishing

Fig. 2. Density wise diameter classes of different tree species at: (a) Upper, (b) Middle and (c) Lower altitudes

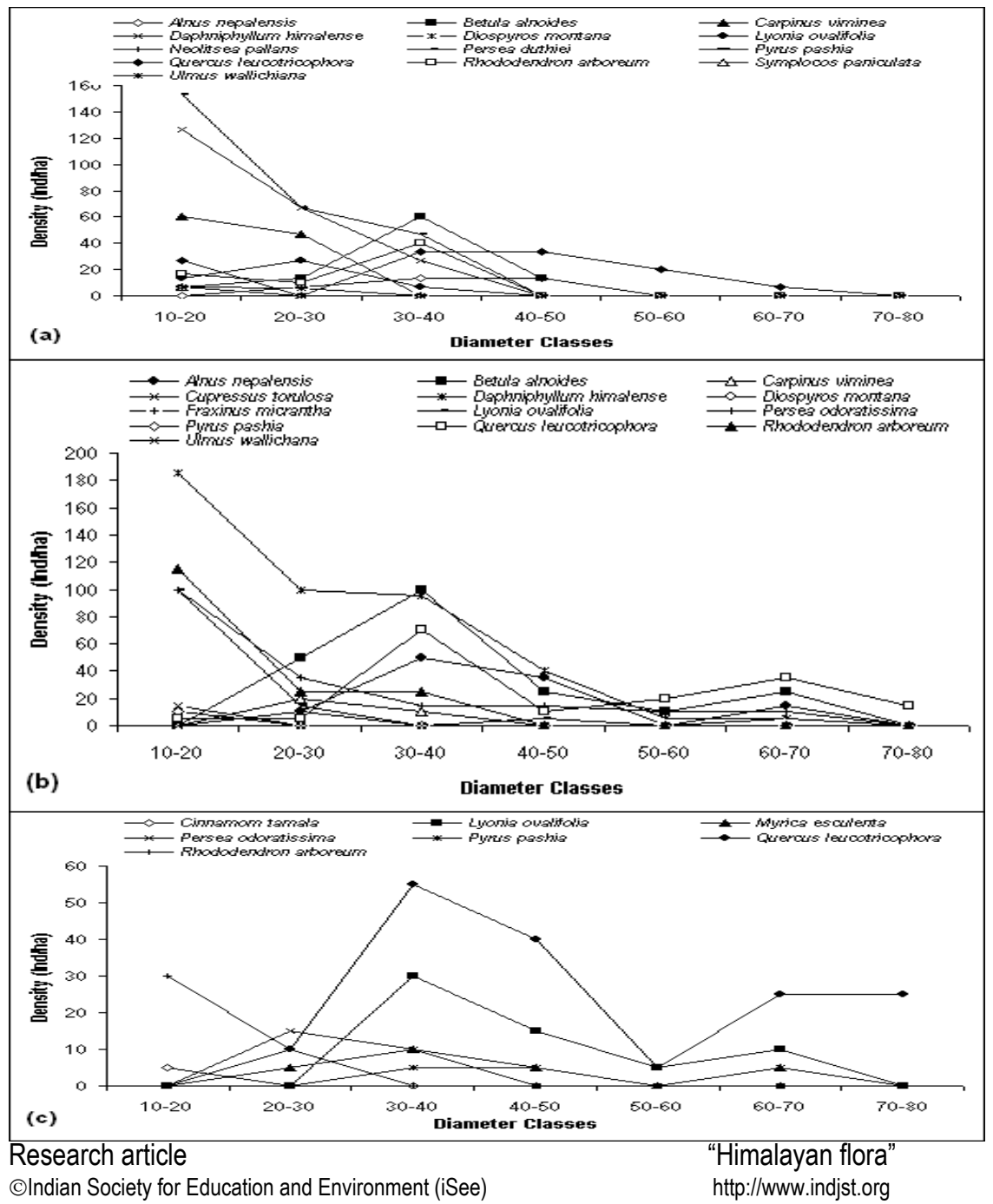

Vol.2 No. 7 (July 2009)

ISSN: 0974- 6846 priorities of conservation for this species.

\section{Materials and Methods}

Study area

The Mandal-Chopta forest of Garhwal Himalaya is located at $30^{\circ} 27.560^{\prime} \mathrm{N}$ latitude and $79^{\circ} 15.234^{\prime} \mathrm{E}$ longitude. The banj oak forests in the area are distributed between 1550 to $2100 \mathrm{~m}$ a.s.I (Table 1). The climate of the area is influenced by monsoon pattern of rainfall. The average annual rainfall ranges between $1900-2600 \mathrm{~mm}$ in these forests, most of which occurs in the monsoon season. The mean monthly minimum temperature ranges between $2.0^{\circ} \mathrm{C}$ (January) and $12.0^{\circ} \mathrm{C}$ (August), whereas mean maximum temperature between $13.0^{\circ}$ (February) and $26.0^{\circ} \mathrm{C}$ (June), with moderate to heavy snowfall in winter season during December to March (Fig. 1). Sampling

After reconnaissance survey, three sites i.e., (i) Upper $\left(2100 \mathrm{~m}\right.$ asl with $45^{\circ}$ slope and on North-East facing aspect), (ii) Middle (1700m asl with $38^{\circ}$ slope and on North facing aspect) and (iii) Lower (1500m asl with $30^{\circ}$ slope and on East facing aspect) of the temperate mixed broad-leaved forest growth were chosen for the determination of structure and composition of vegetation. The sampling was done by establishing ten plots of $10 \mathrm{~m} \times 10 \mathrm{~m}$ size randomly on each site. The woody vegetation was analyzed for species richness, density and diversity at all the three altitudes, following standard methods (Curtis \& Mclntosh 1950; Phillips, 1959; Whittaker, 1972). Species richness was simply the species related diversity, which is the number of species per specified number of individuals (Margalef, 1958). The ratio of abundance to frequency indicated the distribution pattern, which was calculated as per Whitford (1949) and reflected regular $(<0.025)$, random (between 0.025 - 0.05) and contagious $(>0.05)$ distributions (Curtis \& Cottam, 1956). The circumference at breast height (cbh) was taken for determination of tree basal area and calculated as $\pi r^{2}$, where $r$ is the radius measured at $1.37 \mathrm{~m}$ height. The basal area of a species was calculated by multiplying the mean tree basal area with density. Total basal area was the sum of basal area of all species present in the site. Tree basal area was used to determine the relative dominance of a species. Importance value index (IVI) was the sum of the values of relative frequency, relative density and relative dominance (Phillips, 1959).

Several species diversity indices incorporate properties, species richness and evenness of the vegetation. Both an 
Table 1. Site characteristics in the Mandal-Chopta forest area of Garhwal Himalaya

\begin{tabular}{|l|c|c|l|l|}
\hline Location/site & $\begin{array}{c}\text { Altitude } \\
(\mathrm{m} . a . s . I)\end{array}$ & $\begin{array}{c}\text { Slope } \\
\left({ }^{\circ}\right)\end{array}$ & \multicolumn{1}{|c|}{ Forest type } & Aspect \\
\hline $\begin{array}{l}\text { Upper site } \\
\text { (Gharsaari) }\end{array}$ & 2100 & 45 & $\begin{array}{l}\text { Mixed Broad- } \\
\text { leaved }\end{array}$ & $\begin{array}{l}\text { North-East } \\
\text { facing }\end{array}$ \\
\hline $\begin{array}{l}\text { Middle site } \\
\text { (Bammana) }\end{array}$ & 1700 & 38 & $\begin{array}{l}\text { Mixed Broad- } \\
\text { leaved }\end{array}$ & $\begin{array}{l}\text { North } \\
\text { facing }\end{array}$ \\
\hline $\begin{array}{l}\text { Lower site } \\
\text { (Khalla) }\end{array}$ & 1550 & 30 & $\begin{array}{l}\text { Quercus- } \\
\text { Lyonia forest }\end{array}$ & $\begin{array}{l}\text { East } \\
\text { facing }\end{array}$ \\
\hline
\end{tabular}

increase in richness and evenness lead to higher numerical values of such diversity indices. A prominent species diversity index is the Shannon-Wiener information index. This index requires the total number of individuals in the sample and the number of individuals of each species for calculating proportional abundance as input variables. The Shannon-Wiener index is relatively independent of sample size and has a tendency towards stressing rare species (Odum, 1983). The species diversity was therefore calculated using Shannon-Wiener index (Shannon \& Weaver, 1963) as: $\mathrm{H}^{\prime}=-\sum n_{\mathrm{i}} / n \log _{2} \mathrm{n}_{\mathrm{i}}$ $/ n$, Where $n_{i}$ was the IVI value of a species and $n$ was the sum of total IVI values of all species in that forest/site. The $\log _{2}$ was converted into $\log _{10}$ as: $H^{\prime}=3.322 \log _{10} n$ $1 / n \sum n_{i} \log _{10} n_{i}$. Another well-known dominance indicator is Simpson's index (Simpson, 1949). This index is heavily weighted towards the most abundant species in the sample but less sensitive to species richness. The index of similarity (IS) between forest sites was calculated following Sorenson (1948), basing on the existing species richness of all the sites as: IS $=2 C / A+B X 100$, Where $C$ is the common number of species in two comparable sites, and $A$ and $B$ are the total number of species in site $A$ and $B$ respectively.

\section{Soil Sampling and analysis}

Soil samples were collected during March to April 2006, from the top $(0-10 \mathrm{~cm})$, middle $(11-30 \mathrm{~cm})$ and lower $(31-60 \mathrm{~cm})$ layers of all the sites. The moisture percentage was determined as per Mishra (1968) and the soil $\mathrm{pH}$ by standard paste technique using $\mathrm{pH}$ meter (Rhodes, 1982). The organic carbon percentage was measured using potassium dichromate method by reduction of organic carbon and subsequently by spectrophotometer. Extractable phosphate was known using sodium bicarbonate extracts (Oleson et al., 1954). Total nitrogen was measured by the standard Kjeldhal procedure (Bremner \& Mulvaney, 1982). Data were analysed for single factor using analysis of variance (ANOVA) (Steel \& Torrie, 1981). Correlation was developed between different vegetational and soil parameters across different sites.

Results

The number of species in a particular forest type varies markedly along the altitudinal range of its growth, which depends on the complex suit of factors that characterize the habitat of individual species. Ecological function of the species involves all kinds of processes, which are inevitably associated with some changes over space, and composition and structure are affected at species level. The fundamental capability of ecosystems to evolve, change and recognize themselves is a prerequisite for the sustainability of viable system (Ashby, 1974). The species in a community grow together in a particular environment because they have a similar requirement for existence in terms of environmental factors (Ter Baak, 1987).

Table 2. Structure and Composition of woody species

\begin{tabular}{|c|c|c|c|}
\hline Species (altitude m. a.s.l) & \begin{tabular}{|c|} 
Density \\
(ind ha ${ }^{-1}$ )
\end{tabular} & $\begin{array}{l}\text { T.B.C. } \\
\left(\mathrm{m}^{2} h^{-1}\right)\end{array}$ & IVI \\
\hline \multicolumn{4}{|l|}{ Upper altitude (2100) } \\
\hline Alnus nepalensis & 33 & 2.54 & 16.57 \\
\hline Betula alnoides & 93 & 5.45 & 31.93 \\
\hline Carpinus viminea & 107 & 2.08 & 27.47 \\
\hline Daphniphyllum himalense & 220 & 5.28 & 53.71 \\
\hline Diospyros montana & 13 & 0.06 & 4.70 \\
\hline Lyonia ovalifolia & 47 & 1.58 & 13.71 \\
\hline Neolitsea pallans & 13 & 0.14 & 4.93 \\
\hline Persea duthiei & 267 & 6.22 & 56.04 \\
\hline Pyrus pashia & 13 & 0.08 & 4.77 \\
\hline Quercus leucotrichophora & 120 & 10.02 & 56.47 \\
\hline Rhododendron arboreum & 67 & 3.81 & 24.89 \\
\hline Symplocos paniculata & 7 & 0.06 & 2.44 \\
\hline Ulmus wallichiana & 7 & 0.05 & 2.41 \\
\hline Total & 1005 & 37.39 & 300.04 \\
\hline \multicolumn{4}{|l|}{ Middle altitude (1700) } \\
\hline Alnus nepalensis & 110 & 11.02 & 30.55 \\
\hline Betula alnoides & 210 & 17.23 & 48.06 \\
\hline Carpinus viminea & 35 & 2.43 & 9.72 \\
\hline Cupressus torulosa & 10 & 0.26 & 2.10 \\
\hline Daphniphyllum himalense & 430 & 17.47 & 66.64 \\
\hline Diospyros montana & 10 & 0.08 & 3.00 \\
\hline Fraxinus micrantha & 10 & 0.11 & 3.03 \\
\hline Lyonia ovalifolia & 120 & 2.22 & 19.68 \\
\hline Persea odoratissima & 185 & 8.60 & 37.24 \\
\hline Pyrus pashia & 10 & 0.11 & 3.03 \\
\hline Quercus leucotrichophora & 160 & 21.00 & 48.02 \\
\hline Rhododendron arboreum & 165 & 3.56 & 24.33 \\
\hline Ulmus wallichiana & 15 & 0.21 & 4.60 \\
\hline Total & 1470 & 84.29 & 300.00 \\
\hline \multicolumn{4}{|l|}{ Lower altitude (1550) } \\
\hline Cinnamom tamala & 5 & 0.08 & 4.23 \\
\hline Lyonia ovalifolia & 60 & 6.32 & 55.58 \\
\hline Myrica esculenta & 25 & 3.67 & 30.19 \\
\hline Persea odoratissima & 25 & 1.17 & 13.30 \\
\hline Pyrus pashia & 15 & 1.79 & 16.98 \\
\hline Quercus leucotrichophora & 160 & 22.06 & 154.23 \\
\hline Rhododendron arboreum & 40 & 1.22 & 25.48 \\
\hline Total & 330 & 36.32 & 299.99 \\
\hline
\end{tabular}

At upper altitude $(2100 \mathrm{~m})$ higher tree density of Persea duthiei King ex Hook. f. (Lauraceae) (267 trees/ha) and Daphniphyllum himalense Benth. (Daphniphyllaceae) (220 trees/ha) was recorded. But
Research article

Clndian Society for Education and Environment (iSee)
"Himalayan flora" http://www.indjst.org
Sharma et al. Indian J.Sci.Technol. 
most of the individuals of these species were confined to lower diameter classes $(10-20 \mathrm{~cm}$ and $20-30 \mathrm{~cm})$, and therefore contributed lower TBC values. Although the density of Quescus leucotrichophora was 120 trees/ha,

Fig. 3. Dominance diversity curves (d-d curves) for woody species at different altitudinal gradients

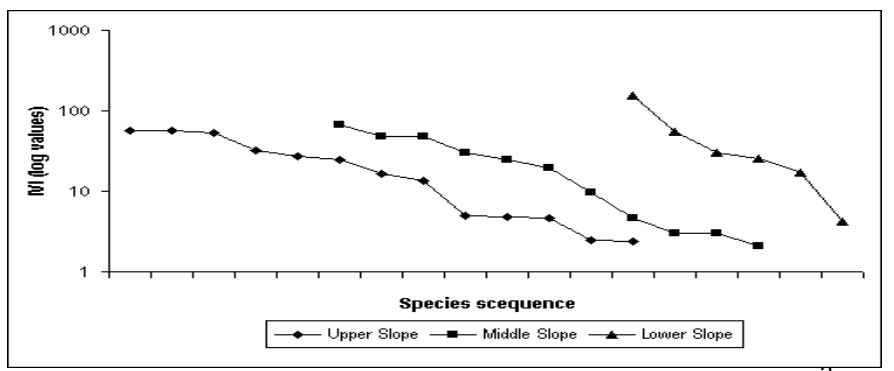

but the TBC value was comparatively high $\left(10.02 \mathrm{~m}^{2} / \mathrm{ha}\right)$ and the individuals were uniformly distributed in lower, middle and higher dbh classes (Fig. 2a). Similarly at middle altitude $(1700 \mathrm{~m})$, the maximum density of $D$. himalense (430 trees/ha) was recorded, but most of them (185 trees/ha in $10-20 \mathrm{~cm}$ and 100 trees/ha in $20-30 \mathrm{~cm}$ dbh classes) were in lower diameter classes. However, the distribution of Betula alnoides Buch.-Ham. ex D. Don (Betulaceae) was recorded in all diameter classes. The $Q$. leucotrichophora forest was comparatively established with more density $\left(160\right.$ trees/ha) and TBC $\left(21.00 \mathrm{~m}^{2} / \mathrm{ha}\right)$ values at this altitude. The individuals of banj oak were more in middle ( 70 trees/ha in $30-40 \mathrm{~cm}$ dbh class) and higher (35 trees/ha in $60-70 \mathrm{~cm}$ dbh class) diameter classes. The number of trees in lower diameter classes was lesser (Figure 2b). A normal forest of banj oak was observed at lower altitude $(1550 \mathrm{~m})$, where highest density $\left(160\right.$ trees/ha) and TBC $\left(22.06 \mathrm{~m}^{2} / \mathrm{ha}\right)$ values of $Q$. leucotrichophora were noticed. Moreover, the banj oak individuals were found distributed in nearly all the dbh classes (55 trees/ha in $30-40 \mathrm{~cm}$ class; 40 trees/ha in $40-$ $50 \mathrm{~cm}$ class; and 25 trees/ha each in $60-70 \mathrm{~cm}$ and $70-$ $80 \mathrm{~cm}$ classes). This may be attributed to the less density and diversity of associated species at this altitude (Fig. 2c).

The tree diversity was highest (3.14) at the higher altitude, while it was 3.09 and 2.10 respectively at middle and lower altitudes (Table 3). At higher altitude the maximum diversity and concentration of dominance $(0.45$ and 0.0354) values were recorded for $Q$. leucotrichophora, followed by $P$. duthiei $(0.45$ and 0.0349$)$ and $D$. himalense (0.44 and 0.0321$)$, and minimum for Symplocos paniculata Thumb. (Symlocaceae) and UImus wallichiana Planchon (Ulmaceae). On the other hand the highest diversity and concentration of dominance values (0.48 and 0.0493) were recorded for $D$. himalense and minimum (0.05 and 0.0000) for Cupressus torulosa D. Don (Cupressaceae) at middle altitude. At lower altitude the maximum diversity and concentration of dominance values (0.49 and 0.2643) were observed for $Q$. leucotrichophora and minimum for Cinnamom tamala
Buch.-Han. (Lauraceae) (Table 3). Beta diversity ( $\beta$ ) values were $3.15,2.89$ and 3.50 respectively, for upper, middle and lower altitudes. The value of species evenness, species richness and Margalef index were minimum $(0.75,7.0$ and 1.19) at lower altitude and maximum $(0.85,13.0$ and 1.80$)$ at higher altitude (Table $3)$. The dominance diversity curve approached a geometric series along all altitudinal gradients (Fig. 3). It is evident that the total actual area occupied by woody plants was $236.88 \mathrm{~m}^{2} /$ ha $(2.36 \%)$.

The soils in the $Q$. leucotrichophora forests, extending from 1550 to $2100 \mathrm{~m}$ elevations were slightly acidic to almost neutral in reaction with a $\mathrm{pH}$ range of 5.7 to 6.6, which was assumed to be the favourable range for nutrients availability of this species. The moisture Fig.4. Correlation between various vegetational parameters on different altitudes
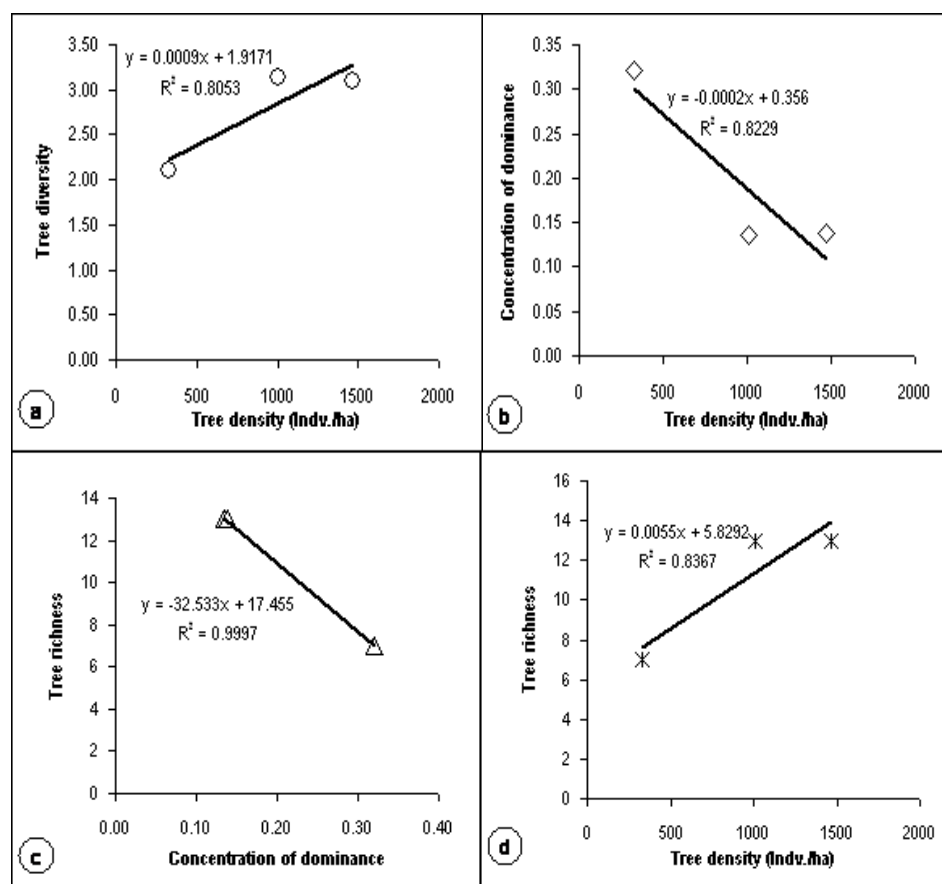

percentage in the soils varied from 14.53 to 17.05 $\%$. The total nitrogen and organic carbon percentage values at all the altitudes ranged between $0.11 \%$ to $0.65 \%$ and $1.02 \%$ to $7.74 \%$. The presence of higher average moisture contents $\quad(15.57 \%$ at higher and $16.01 \%$ at middle altitudes),

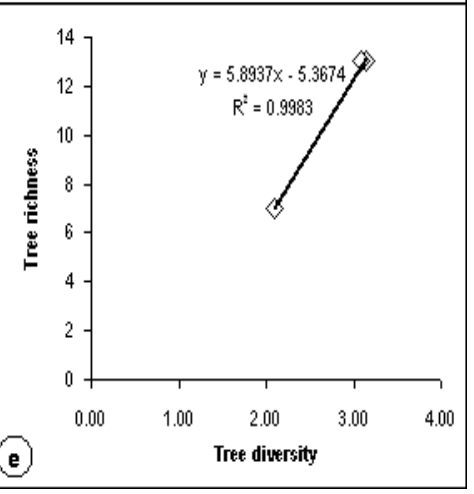
availability of higher average organic carbon $(3.91 \%$ at higher and $3.61 \%$ at middle altitudes) and nitrogen contents $(0.36 \%$ at higher and $0.38 \%$ at middle altitudes) in the soils of $2100 \mathrm{~m}$ and $1700 \mathrm{~m}$ altitudes respectively
Research article

Clndian Society for Education and Environment (iSee)
"Himalayan flora" http://www.indjst.org
Sharma et al. Indian J.Sci.Technol. 
might have given birth to higher diversity (3.140 and 3.092) and total basal cover values $\left(37.39 \mathrm{~m}^{2} / \mathrm{ha}\right.$ at higher altitudes and $84.29 \mathrm{~m}^{2} /$ ha at middle altitudes) (Table 2, 4) on these altitudes. The maximum (91.50 kg/ha) and minimum $(44.0 \mathrm{~kg} / \mathrm{ha})$ potassium values were recorded for higher and lower altitudes respectively. The presence of higher diversity at higher altitudes is believed to be related with higher potassium release (Sharpe et al., 1992).

The correlation between different vegetational parameters along altitudinal gradient is given in Fig. 4a$4 \mathrm{e}$. The tree density was positively correlated with the tree diversity and tree richness $(P<0.001)$ and negatively with tree concentration of dominance at $\mathrm{P}<0.001$. The cd was negatively correlated with tree richness and tree diversity was positively correlated with tree richness. On the other hand the correlation between vegetational parameters (tree density and Total Basal Cover) vs soil parameters (total nitrogen, available phosphate, available potash and organic carbon) were positively correlated (Fig. 5a- 5h).

\section{Discussion}

The results revealed that the total basal cover ( 36.32 to $84.29 \mathrm{~m}^{2} / \mathrm{ha}$ ) and the total tree density (330 to 1470 individuals/ha) values were comparable to the moist temperate forests of other parts of Himalaya (Table 2). Earlier several workers like Baduni (1996), Ghildiyal et al. (1998), Sharma and Baduni (2000), Ram et al. (2004) have reported the values of TBC and density from 17.9 to $180.1 \mathrm{~m}^{2} / \mathrm{ha}$ and 270 to 1670 individuals/ha respectively, for temperate forests. The total diversity values were comparable with those reported for the temperate forests by Monk (1967), Singh and Singh (1987). The concentration domination (cd) values (0.135 at higher altitude, 0.139 at middle altitude and 0.321 at lower altitude) were more or less similar to those reported by Risser and Rice (1971) for certain

Research article

Table 3. Structure and composition of woody species at various altitudes

\begin{tabular}{|l|c|c|c|}
\hline Components & $\begin{array}{c}\text { Upper altitude } \\
(2100 \mathrm{~m} \text { asl })\end{array}$ & $\begin{array}{c}\text { Middle altitude } \\
(1700 \mathrm{~m} \text { asl })\end{array}$ & $\begin{array}{c}\text { Lower altitude } \\
(1550 \mathrm{~m} \text { asl })\end{array}$ \\
\hline $\mathrm{H}^{\prime}$ & 3.14 & 3.09 & 2.10 \\
\hline $\mathrm{Cd}$ & 0.1350 & 0.1389 & 0.3213 \\
\hline $\begin{array}{l}\text { Simpson's } \\
\text { Diversity }\end{array}$ & 12.865 & 12.861 & 6.679 \\
\hline Beta diversity & 3.15 & 2.89 & 3.50 \\
\hline Equitability & 0.85 & 0.84 & 0.75 \\
\hline Species Richness & 13.0 & 13.0 & 7.0 \\
\hline Margalef Index & 1.80 & 1.67 & 1.19 \\
\hline
\end{tabular}

CIndian Society for Education and Environment (iSee)
"Himalayan flora"

Fig.5. Correlation between vegetational and soil parameters across different altitudinal gradients
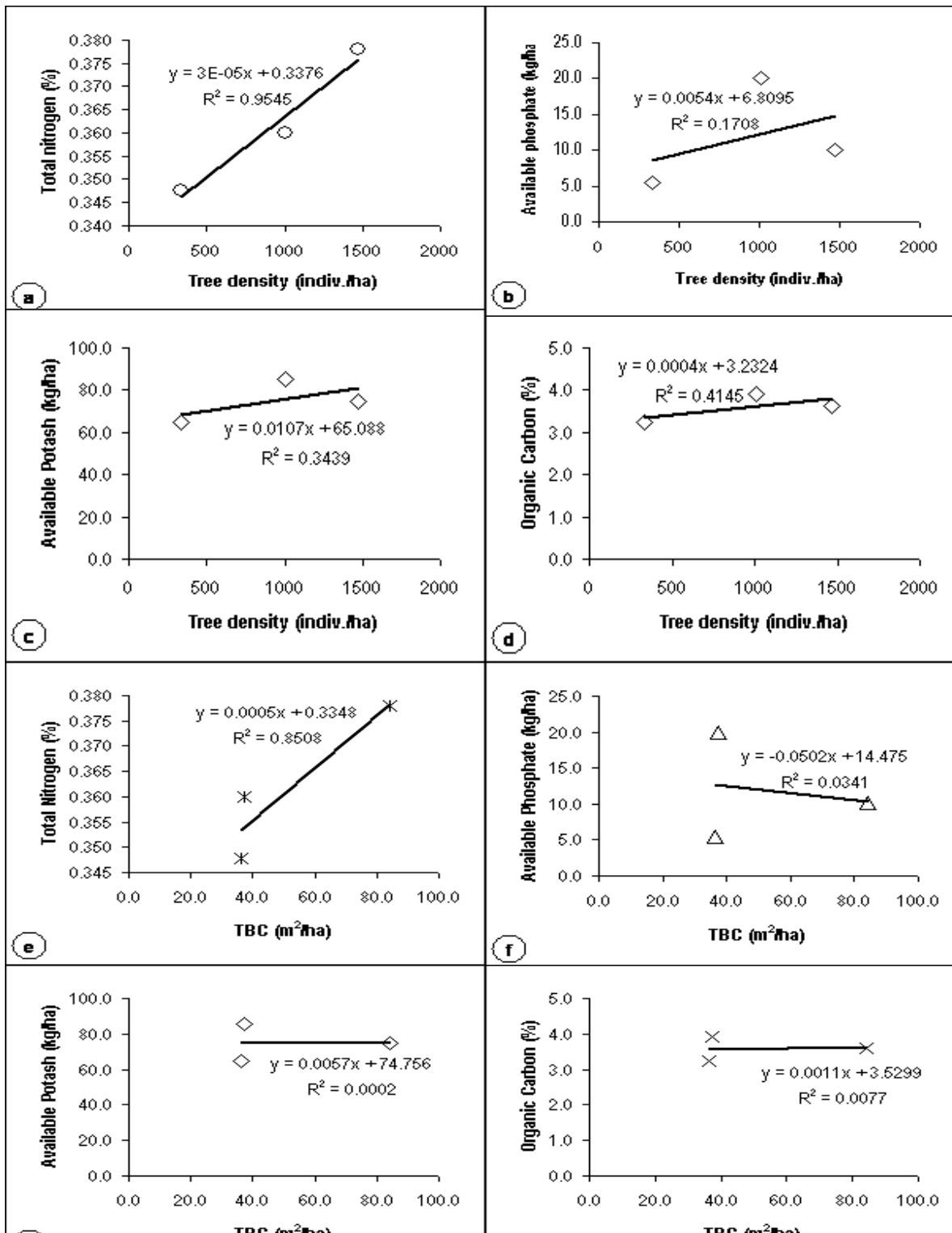

(a) TBC (m²

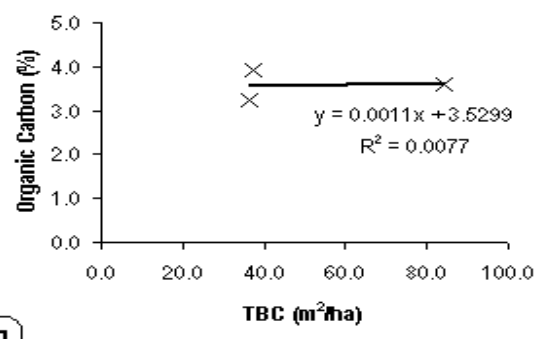

temperate vegetation. Tiwari and Singh (1985) also observed concentration of dominance (cd) values between 0.11 and 0.93 for tree layer in the temperate forests of Kumaon Himalaya.

The

rural

habitations in Garhwal Himalaya are mostly situated up to $2000 \mathrm{~m}$ a.s.l, which is also the preferred zone of banj oak forest in this area. At some places, due to summer nomadic settlements, the

Sharma et al. Indian J.Sci.Technol. 
Table 4. Physico-chemical characteristics of the soil at different altitudes

\begin{tabular}{|l|l|c|c|c|c|c|c|c|}
\hline $\begin{array}{l}\text { Location/ } \\
\text { Altitude } \\
(\mathrm{m} \text { a.s.I. })\end{array}$ & Soil layer & $\begin{array}{c}\text { Depth } \\
(\mathrm{cm})\end{array}$ & $\begin{array}{c}\text { Moisture } \\
(\%)\end{array}$ & $\mathrm{pH}$ & $\begin{array}{c}\text { Total } \\
\text { Nitrogen } \\
(\%)\end{array}$ & $\begin{array}{c}\text { Available } \\
\text { Phosphate } \\
(\mathrm{kg} / \mathrm{ha})\end{array}$ & $\begin{array}{c}\text { Available } \\
\text { Potash } \\
(\mathrm{kg} / \mathrm{ha})\end{array}$ & $\begin{array}{c}\text { Organic } \\
\text { Carbon } \\
(\%)\end{array}$ \\
\hline $\begin{array}{l}\text { Upper } \\
\text { altitude } \\
(2100)\end{array}$ & Top layer & $0-10$ & 15.92 & 5.90 & 0.62 & 21.00 & 91.50 & 7.74 \\
\cline { 2 - 9 } & Middle layer & $11-30$ & 15.85 & 5.85 & 0.28 & 20.00 & 91.50 & 2.43 \\
\cline { 2 - 9 } Average & Lower layer & $31-60$ & 14.95 & 5.70 & 0.18 & 19.00 & 73.50 & 1.56 \\
\hline $\begin{array}{l}\text { Middle } \\
\text { altitude } \\
(1700)\end{array}$ & Top layer & $0-10$ & 17.57 & 5.82 & 0.36 & 20.00 & 85.50 & 3.91 \\
\cline { 2 - 9 } & Middle layer & $11-30$ & 15.94 & 6.60 & 0.52 & 12.32 & 84.00 & 5.02 \\
\hline Lower layer & $31-60$ & 15.05 & 6.10 & 0.27 & 7.68 & 69.00 & 2.64 \\
\hline $\begin{array}{l}\text { Average } \\
\text { Lower } \\
\text { altitude } \\
(1550)\end{array}$ & Top layer & $0-10$ & 15.67 & 6.35 & 0.38 & 10.08 & 75.00 & 3.61 \\
\cline { 2 - 9 } & Middle layer & $11-30$ & 15.05 & 5.90 & 0.28 & 5.00 & 66.00 & 2.69 \\
\cline { 2 - 8 } \\
\hline Lverage & Lower layer & $31-60$ & 14.53 & 5.90 & 0.11 & 5.00 & 44.00 & 1.02 \\
\hline
\end{tabular}

exploitation of the oak forests extends up to $2500 \mathrm{~m}$ a.s.l. The oaks are treated traditionally as the most common and easy accessible multipurpose trees by the inhabitants. The $Q$. leucotrichophora forests, when exposed to adverse influences, the exceptionally hard oak itself persists in the form of scrubs and all other associates except Rhododendron arboretum and Lyonia ovalifolia Wall (Ericaceae) (which are not eaten by cattle and are of very poor fuel value) are killed out. In the extreme case, even oak may succumb leaving an open pure stand of Rhododendron arboretum Smith (Ericaceae). Therefore, the protection of oak species is essential for maintaining the stability, species richness and vigour of temperate forests in Garhwal Himalaya.

The study points out an urgent need for the conservation of biodiversity of the banj oak forests of Garhwal Himalaya. Strict protection and regulatory measures are required for its conservation, however, such measures will fail unless fuel and fodder requirements of the local inhabitants are met. It was estimated that the wood extracted from these forests meets $81-100 \%$ energy needs of the local populations, and as much as $38 \%$ of the total wood extracted is marketed for buying food grain and other requirements. These forests also support $80-95 \%$ of the fodder needs (Singh \& Singh 1992). Therefore systematic fuel-wood plantations of fast growing trees on the village commons should be encouraged by setting aside selected forest compartments for raising high density short rotation energy plantations. Contrivances for developing village pastures with a mixture of grasses and legumes with scattered native fodder trees (such as Grewia oppositifolia Roxb. ex Mast (Tiliaceae), Celtis australis Hook. f. (Ulmaceae), Ficus gibbosa Blume. (Moraceae), etc.), could be a viable strategy for easing the anthropogenic pressure on these forests. Further, there is a need to integrate the livelihood of local human populations with conservation measures through participatory forest management in such a way so that the
Frankfurt M. pp: 416.

ISSN: 0974- 6846

local inhabitants are able to draw a large share of benefits from conservation of these forests.

\section{Acknowledgements} Authors are thankful to the Department of Science and Technology (DST), Government of India, for providing financial support vide its Project No. SP/SO/PS52/2004.

\section{References}

1. Ashby WR (1974) Einfuhrung in die kybernetik.
2. Baduni NP (1996) Growing stock variation in different forest cover types of Pauri Garhwal. D. Phil. thesis, HNB Garhwal University, Srinagar (Garhwal) Uttaranchal, India. pp: 261.

3. Bastian O (1990) Structure, function and change- three main aspects in investigation of biotic landscape component. Ekologia (CSFR), Bratislava 9 (4), 405-418.

4. Begon M, Harper JC and Townsend CR (1990) EcologyIndividuals, Populations and Communities. Chapter 4, London: Blackwell Scientific Publ., UK, $2^{\text {nd }}$ edition.

5. Bremner JM and Mulvaney CS (1982) Nitrogen total. In: Page, A.C., R.H. Miller and D.R. Kieney (Eds.) Method of Soil Analysis- Part 2: Chemical and Microbiological methods ( $2^{\text {nd }}$ eds.) Agronomy series No. 9 pp: 595-624. Medison, WI: American Society for Agronomy and Soil Sciences.

6. Champion HG and Seth SK (1968) The Forest Type of India. Delhi: The Manager of Publications.

7. Curtis JT and Cottam G (1956) Plant Ecology Work Book Laboratory Field Reference Manual pp: 193 Minnesota: Burgess Pub. Co.

8. Curtis JT and Mclntosh RP (1950) The interrelation of certain analytic and synthetic phytosociological characters. Ecology. 31, 434-455.

9. Franklin JF (1988) Structural and functional diversity in temperate forests. In: EO Wilson, (Ed) pp: 199-175. Washington, DC: Biodiversity National Academy Press.

10. Ghildiyal SK, Baduni NP, Khanduri VP and Sharma CM (1998) Community Structure and composition of oak forests along altitudinal gradient in Garhwal Himalaya. Ind. J. For. 21(3), 242-247.

11. Kalakoti BS, Pangtey YPS and Saxena AK (1986) Quantitative analysis of high altitude vegetation of Kumaon Himalaya. J. Ind. Bot. Soc. 6, 384-396.

12. Maarel E van der (1988) Species diversity in plant communities in relation to structure and dynamics. In: Diversity and Pattern in Plant Communities. H. J. During $\mathrm{HJ}$ et al. (Eds.), Diversity and Pattern in Plant
Research article

CIndian Society for Education and Environment (iSee)
"Himalayan flora" http://www.indjst.org
Sharma et al. Indian J.Sci.Technol. 
Communities, Netherlands: The Hague, pp: 1-14. Netherlands: The Hague.

13. Magurran AE (1988) Ecological Diversity and Management. Princeton: Princeton University Press.

14. Margalef DR (1958) Information theory in ecology. Genet. Syst. 3, 36-71.

15. Mishra R (1968) Ecology Workbook p. 244. Calcutta: Oxford and IBH Publ. Co.

16. Monk CD (1967) Tree species diversity in the Eastern deciduous forest with particular reference to NorthCentral Florida. Am. Nat. 101, 173-187.

17. Muller-Dombois and D Ellenberg (1974) Aims and Methods of vegetation Ecology. John Wiley \& Sons, p. 547. New York, London, Sydney, Toronto:, John Wiley and Sonspp: 547.

18. Noss RF (1990) Indicators for monitoring biodiversity: a hierarchical approach. Conserv. Biol. 4(4), 355-364.

19. Noss RF and Cooperrider AY (1994) Saving Nature's Legacy. Washington, DC: Island Press.

20. Odum HT (1983) System Ecology: an introduction. New York: John Wiley.

21. Oleson SR, Cole CV, Watanable FS and Dean LA (1954) Estimation of available phosphorus in soil by extraction with sodium bicarbonate. USDA Circular. 939, 1-19.

22. Phillips EA (1959) Methods of Vegetation Study. pp. 107. New York: Henry Halt and \& Co., New York.. Inc., pp:107.

23. Puri GS (1960) Indian Forest Ecology. Vol. I, . Oxford Book \& Stationary Company, New Delhi. and Calcutta, India: Oxford Book and Stationary Company.

24. Ralhan PK, Saxena AK and Singh JS (1982) Analysis of forest vegetation at and around Nainital in Kumaun Himalaya. Proc. Ind. Nat. Sci. Acad. 48, 122-128.

25. Ram J, Kumar A and Bhatt J (2004) Plant diversity in six forest types of Uttaranchal, Central Himalaya, India. Curr. Sci. 86(7), 975-978.

26. Rhodes JD (1982) Soluble salts. In: Page, A.C., Miller, R.H. and Kieney, D.R. (Eds.) Method of soil analysisPart 2: Chemical and microbiological methods $\left(2^{\text {nd }}\right.$ ed.) Agronomy series No. 9. Page AC, Miller RH \& Kieney DR (Eds.). pp: 167-180. Medison, WI: American Society for Agronomy and \& Soil Sciences, pp: 167-180..

27. Risser PG and Rice EL (1971) Diversity in tree species in Oklahoma upland forests. Ecology. 52, 876-880.

28. Sagar R, Raghubanshi AS and Singh JS (2003) Tree species composition, dispersion and iversity along a disturbance gradient in a dry tropical forest region in India. For. Ecol. Manage. 186, 61-71.

29. Sahu PK, Sagar R and Singh JS (2008) Tropical forest structure and diversityin relation to altitude and disturbance in a Biosphere reserve in Central India. Appl. Veg. Sci. 11: , 461-470.

30. Saxena AK and Singh JS (1982) A phytosociological analysis of forest communities of a part of Kumaun Himalaya. Vegetatio. 50, 3-22.

31. Shannon CE and Wiener W (1963) The Mathematical Theory of Communication. University of Illinois Press, Urbana, USA, p: 117.
32. Sharma CM and Baduni NP (2000) Effect of aspect on the structure of some natural stands of Abies pindrow in Himalayan moist temperate forests. The Environmentalist. 20, 309-317.

33. Sharma CM and Sumeet Gairola (2007) Prospects of Carbon Management in Uttarakhand: An overview. Samaj Vigyan Shodh Patrika (Special IssueUttarakhand-1) pp: 23-34.

34. Sharpe WE, Swistock BR and Dewalle DR (1992) A greenhouse study of northern red Oak seedling growth of two forest soils at different stages of acidification. Water, Air, Soil Poll. 66, 121-133.

35. Simpson EH (1949) Measurement of diversity. Nature . 163,688

36. Singh RS and Singh SP (1987) Forest vegetation of the Himalaya. Bot. Rev. 53, 8-192.

37. Singh VP and Singh JS (1992) Energetics and environmental costs of agriculture in a dry tropical region of India. Environ. Manage. 16, 495-503.

38. Sorenson T (1948) A method of establishing groups of equal amplitude in plant sociology based on similarity of species content. Detkong Danske Vidensk Selk Boil. Skr. (Copenhagen) 5, 1-34.

39. Steel RGD and Torrie JH (1981) Principles and Procedures of Statistics: A Biometrical Approach, Singapore: McGraw-Hill Book Company.

40. Tang CQ and Ohsawa M (1997) Zonal transition of evergreen, deciduous and coniferous forest along the altitudinal gradient on humid subtropical mountains, MT. Emei, Sichuan, China. Plant Ecol. 133, 63-78.

41. Ter Baak CJF (1987) The analysis of vegetation environmental relationship by canonical correspondence analysis. Vegetatio. 69, 69-77.

42. Tiwari JC and Singh SP (1985) Analysis of woody vegetation in a mixed oak forest of Kumaun Himalaya. Proc. Ind. Nat. Sci. Acad. 51(B), 232-247.

43. Wanga $P$ and Ohsawa $M$ (2006a) Structure and regeneratation dynamics of dominant tree species along altitudinal gradient in a dry valley slopes of the Bhutan Himalaya, For. Ecol. Manage. 230, 136-150.

44. Wanga $P$ and Ohsawa $M$ (2006b) Forest pattern analysis along the topographical and climatic gradient of the dry west and humid east slopes of Dochule, western Bhutan. Bhu. J. RNR2, 1-17.

45. Wanga $P$ and Ohsawa M (2006c) Gradational forest change along the climatically dry valley slopes of Bhutan in the midst of humid eastern Himalaya. Plant Ecol. 186 (1), 109-128.

46. Whitford PB (1949) Distribution of woodland plants in relation to succession and clonal growth. Ecology. 30, 199-288.

47. Whittaker R H (1965) Dominance and diversity in land plant communities. Science. 147, 250-260.

48. Whittaker RH (1972) Evolution and measurement of species diversity. Taxon. 21, 213-251.
Research article

CIndian Society for Education and Environment (iSee)
"Himalayan flora" http://www.indjst.org
Sharma et al. Indian J.Sci.Technol. 